\title{
DIÁLOGOS SOBRE CURRÍCULO E FORMAÇÃO
}

\author{
André Malina \\ Universidade Federal do Rio de Janeiro, Rio de Janeiro, Rio de Janeiro, Brasil.
}

Leon Ramyssés Vieira Dias

Rede Municipal de Araruama, Araruama, Rio de Janeiro, Brasil.

Ângela Celeste Barreto de Azevedo

Universidade Federal do Rio de Janeiro, Rio de Janeiro, Rio de Janeiro, Brasil.

A formação profissional em Educação Física parece ter um espaço significativo em produções acadêmico-científicas. Dessas, a temática do currículo não tem, necessariamente, ocupado o mesmo espaço, embora não se possa pensar em formação profissional sem pensar o currículo.

Nesse sentido, veio em boa hora a coletânea de textos Educación Física em América Latina: currículos y horizontes formativos, organizados por Ana Márcia Silva e Victor Molina Bedoya e publicado em 2017 pela editora Paco Editorial, sediada em São Paulo.

Nos textos, pode-se verificar que houve a tentativa de aglutinar pesquisadores de diferentes países em diálogo sobre a América Latina na temática elencada, como mostra a apresentação do livro:

\footnotetext{
América Latina em foco, fue el nombre Del proyecto de investigación desde el cual se buscó articular a investigadores y estudiosos del campo em esta parte del mundo. El nombre no pudo resultar más acertado al propósito de estrechar los lazos de colaboración académica y cultural entre investigadores de doce países, lo mismo que el diálogo entre personas e instituciones comprometidas com la potenciación de um campo tan importante par el acaecer de las sociedades actuales y futuras. (SILVA e BEDOYA, 2017, p.6).
}

Embora com viés de aglutinação entre pesquisadores de vários países, a diversidade foi o percurso objetivado pelos organizadores. Mesmo não aparecendo no título, é afirmado: 1) na orelha do livro: "Reinvidicamos para el vasto campo de la Educación Física, condiciones de posibilidad para la existência en lo diverso"; 2) na capa com o Estado Inca, também na orelha do livro: "De allí que com la figura Del Tawantinsuyo [...] que ilustra la cubierta del libro se pretende representar la diversidade [...] que caracteriza al continente latinoamericano"; 3) na curta apresentação: "Así, mas que unificar, el texto expone la diversidade de concepciones, formas de ser y de hacer desde el campo de la Educación Física [...], de um diálogo de saberes y de seres"; e 4) na contracapa (que é uma compilação de três parágrafos da apresentação com modificações formais): "Há guiado em todo momento la investigación, el reconocimiento del carácter diverso y plural de nuestros países".

Na coletânea, 46 autores trabalharam nove textos com temáticas diversas, buscando mostrar um panorama da questão do currículo mediado com temáticas que, segundo os textos mostram, aparecem mais ou menos nos currículos.

Embora faça parte da formação profissional, a questão do currículo não necessariamente foi privilegiada no título dos textos do livro, aparecendo em somente três deles. Mostram-se os temas de formação e formação docente com um texto cada; e formação profissional com três, além de um texto que privilegia os estudos comparados.

Uma ressalva a fazer, que não ocorre unicamente nesse texto, é a denominação do título e em textos da coletânea, de América Latina. Embora não expresse explicitamente que o 
conjunto dos escritos represente um pensamento abrangente, espera-se, ao ler o título, ver a América Latina contemplada para além da América do Sul de forma recorrente.

A denominação de América Latina tem um corte cultural e é, genuinamente, linguística, pois se trata de especificar países que tem origem no latim. Os países da América do Sul, América Central e o México compõem o que se chama de América Latina. Já é um recorte um pouco artificial, pois, além do México, os Estados Unidos não têm uma língua oficial, embora o inglês seja predominante. $\mathrm{O}$ sul dos Estados Unidos, entretanto, foi fruto de anexação forçada, com forte influência latina. Mesmo o Canadá, mais ao norte, tem o francês como língua (neolatina) principal na região de Montreal.

Como pesquisadores da Educação Física, conhecemos pouco sobre a América Latina, talvez mais sobre países próximos, como a Argentina. Percebe-se, no entanto, um esforço contínuo de intercâmbio de ideias, à distância e presencialmente, principalmente, na perspectiva sociocultural, em pesquisas articuladas e nos eventos bianuais do Conice/Conbrace.

As Guianas, a América Central e o Caribe (com exceção, talvez, de Cuba), não são muito familiares. Não se tem conhecimento suficiente sobre o que pensam e como estruturam a formação profissional e o currículo da formação em Educação Física. Isso não retira a importância do livro que agora é ofertado aos leitores. Nele, inclusive, há análises sobre a questão de gênero no México, entre outros países, (NICOLINO et al., 2017) e sobre a questão da formação em administração esportiva em Cuba, análise feita também em conjunto com vários países (D’AMICO; BASTOS; HOJAS, 2017), revelando o esforço de mostrar um panorama geral de países da América Latina.

De forma específica, houve artigos que explicitaram questões do Brasil, da Argentina, do Uruguai, do Peru, do Chile, da Colômbia, da Venezuela, do México, de Cuba, e um artigo de estudo comparado com base em uma análise quantitativa que fornece dados, em especial, sobre a Psicologia do Esporte da Costa Rica e do Equador (REYNAGA-ESTRADA et al., 2017), dentre outros países já citados.

A obra em questão não foi o único esforço dos organizadores da coletânea, pois já haviam publicado um livro anteriormente, em 2015, pela mesma editora, versando sobre a questão da formação profissional. Este está disponibilizado gratuitamente no ambiente da internet, mediante busca simples e já conta com uma resenha delineando o percurso do livro (FONSECA, SOUZA NETO e YAOCHITA, 2018).

Retomando a ideia de diversidade dos autores da coletânea, há o cuidado de mostrar a necessidade de - em termos de América Latina - unidade na diversidade. Pode-se, a partir daí, retomar um antigo e necessário (especialmente no momento atual) filósofo que afirmava na construção do seu Método: "o concreto é concreto por ser síntese de múltiplas determinações, logo, unidade na diversidade" (MARX, 1983, p. 218). Conforme mostram os autores da coletânea: "[...] intencionados por la unidad em la diferencia y desde allí poder ensamblar nuestras dignidades em procura del mundo más justo y solidário com el que soñamos".

Vale, e muito, o estudo e a leitura!

\section{Referências}

D’AMICO, Rosa López de; BASTOS, Flávia da Cunha; HOJAS, Juan. Gerencia Deportiva em Latino América: formación del talento humano. In: SILVA, Ana Márcia; BEDOYA, Victor Molina. Educación Física en América Latina: currículos y horizontes formativos. São Paulo: Paco Editorial, 2017, p 37-62. 
FONSECA, Rubiane Giovani; SOUZA NETO, Samuel de; YAOCHITE, Roberto Tadeu. Formação Profissional em Educação Física na América Latina: diversidade e desafios. Pensar a Prática. Goiânia, v. 21, n. 4, out./dez. 2018, p. 968-971.

MARX, Karl. Contribuição à Crítica da Economia Política. São Paulo: Martins Fontes, 1983.

NICOLINO, et al. Educação Física e Gênero: um estudo panorâmico da legislação e dos currículos de formação docente da América Latina. In: SILVA, Ana Márcia; BEDOYA, Victor Molina. Educación Física em América Latina: currículos y horizontes formativos. São Paulo: Paco Editorial, 2017, p 63-105.

REYNAGA-ESTRADA, Pedro et al. La Psicología del Deporte em los Planes de Estudio de Cultura Física em Paises Latinonamericanos. Estudio Comparado. In: SILVA, Ana Márcia; BEDOYA, Victor Molina. Educación Física en América Latina: currículos y horizontes formativos. São Paulo: Paco Editorial, 2017, p. 169-191.

SILVA, Ana Márcia; BEDOYA, Victor Molina. Presentación. In: SILVA, Ana Márcia; BEDOYA, Victor Molina. Educación Física en América Latina: currículos y horizontes formativos. São Paulo: Paco Editorial, 2017, p. 5-7.

Endereço para correspondência:

andremalina@yahoo.com.br

André Malina

Universidade Federal do Rio de Janeiro

Escola de Educação Física e Desportos - Dep. de Luta

Avenida Carlos Chagas Filho, 540 - sala

21941-599 - Cidade Universitária, Rio de Janeiro -RJ /Brasil. 